\title{
Safety of Apixaban for Cancer-Associated Thrombosis
}

\author{
Behnood Bikdeli 1,2,3 David Jiménez ${ }^{4,5,6}$ \\ ${ }^{1}$ Cardiovascular Medicine Division, Brigham and Women's Hospital, \\ Harvard Medical School, Boston, Massachusetts, United States \\ ${ }^{2}$ Center for Outcomes Research and Evaluation (CORE), Yale \\ University School of Medicine, New Haven, United States \\ ${ }^{3}$ Cardiovascular Research Foundation (CRF), New York, United States \\ 4 Respiratory Department, Ramón y Cajal Hospital, IRYCIS, Madrid, \\ Spain \\ ${ }^{5}$ Medicine Department, Universidad de Alcala, IRYCIS, Madrid, Spain \\ ${ }^{6}$ CIBER de Enfermedades Respiratorias (CIBERES), Instituto de Salud \\ Carlos III, Madrid, Spain
}

Thromb Haemost 2021;121:547-551.

Venous thromboembolism (VTE) is a common complication in patients with cancer and is associated with significant morbimortality and adverse outcomes. ${ }^{1}$ Management of cancer-associated thrombosis poses challenges for clinicians. Compared with other patients with VTE, patients with cancer-associated VTE who receive anticoagulant therapy have a higher risk both for recurrent VTE and for bleeding complications. ${ }^{2}$ Until recently, subcutaneous low-molecularweight heparin (LMWH) monotherapy has been the standard of treatment for cancer-associated thrombosis. ${ }^{3-5}$ Compared with vitamin $\mathrm{K}$ antagonists, LMWHs may lead to reduction in VTE events though not in bleeding or mortality. ${ }^{6}$

Direct oral anticoagulants (DOACs) have become the anticoagulant treatment of choice for the majority of patients with acute VTE. ${ }^{3}$ Compared with vitamin $\mathrm{K}$ antagonists, in most subgroups, they are similar in efficacy but are associated with lower risk of major bleeding. ${ }^{7}$ In addition, these drugs are given in fixed doses and do not require laboratory monitoring of the anticoagulant effect. Several trials have assessed the efficacy and safety of DOACs for patients with cancer-associated thrombosis. ${ }^{8-11}$ A recent meta-analysis included four randomized trials $(2,907$ patients with cancer-related VTE) that compared apixaban (two trials), edoxaban (one trial), or rivaroxaban (one trial) with dalteparin. ${ }^{12}$ Risk for recurrent VTE was 3.5\% absolute points lower in patients treated with a DOAC, but clinically relevant nonmajor bleeding (CRNMB) was $4.7 \%$ higher. Though the risk of major bleeding was nonsignificantly higher, DOACs had a $6.6 \%$ significant absolute increase in the subgroup who had gastrointestinal cancer. ${ }^{12}$ Broadly similar observations have been noted in other meta-analyses

received

January 19, 2021

accepted

January 19, 2021

published online

January 20, 2021
Address for correspondence David jiménez, MD, PhD, Respiratory Department, Ramón y Cajal Hospital, IRYCIS, 28034 Madrid, Spain (e-mail: djimenez.hrc@gmail.com).

of the DOACs for the treatment of acute VTE associated with cancer. $^{13}$

The study by Ageno et al in this issue of Thrombosis and Haemostasis is a welcome addition to the body of evidence. ${ }^{14}$ Using data from the multicenter, randomized, open-label, noninferiority Caravaggio trial, ${ }^{11}$ the authors investigated sites of bleeding, clinical presentation, and course of major bleeding. Among 576 patients randomized to apixaban, major bleeding occurred in 22 (3.8\%) patients, compared with 23 of $579(4.0 \%)$ patients randomized to dalteparin. The sites of major bleeding were similar between the two treatment groups. The clinical presentation of major bleeding was severe or fatal in 6 patients on apixaban and in 5 patients on dalteparin, while the clinical course was severe in 5 patients on apixaban and in 7 patients on dalteparin. Major bleeding occurred in 9 patients with gastrointestinal cancer in each treatment group. Finally, there were 52 CRNMBs in the apixaban group and 35 in the dalteparin group. Strengths of the study include high-quality data and thorough reporting. Study limitations comprise lack of competing risk assessment, and a low number of bleeding events that precludes further phenotyping, if a true difference were to exist.

The results reported by Ageno et al come from the largest trial to date evaluating the efficacy and safety of a DOAC for patients with cancer-associated thrombosis and suggest that treatment with apixaban might be associated with a better safety profile than other DOACs. In the Hokusai VTE Cancer Trial, major bleeding occurred in 36 patients (6.9\%) in the edoxaban group and in 21 patients (4.0\%) in the dalteparin group (hazard ratio [HR], 1.77; 95\% confidence interval [CI], 1.03-3.04) (- Table 1). There was also more CRNMB in patients receiving edoxaban (c) 2021. Thieme. All rights reserved. Georg Thieme Verlag KG,

Rüdigerstraße 14,

70469 Stuttgart, Germany
DOI https://doi.org/ $10.1055 / \mathrm{a}-1367-7830$ ISSN 0340-6245. 
Table 1 Major randomized trials of direct oral anticoagulants for the treatment of cancer-associated thrombosis

\begin{tabular}{|c|c|c|c|}
\hline Study & Hokusai Cancer VTE ${ }^{8}$ & SELECT-D $^{9}$ & Caravaggio $^{11}$ \\
\hline Inclusion criteria & $\begin{array}{l}\text { Male or female subjects } \\
\text { with age } \geq 18 \text { years } \\
\text { Confirmed symptomatic } \\
\text { or unsuspected VTE } \\
\text { Cancer (other than basal- } \\
\text { cell or squamous-cell car- } \\
\text { cinoma of the skin), either } \\
\text { active or diagnosed within } \\
2 \text { years prior to randomi- } \\
\text { zation } \\
\text { Intention for long-term } \\
\text { treatment with parenteral } \\
\text { LMWH } \\
\text { Able to provide written } \\
\text { informed consent }\end{array}$ & $\begin{array}{l}\text { Active cancer (other than } \\
\text { basal-cell or squamous-cell } \\
\text { carcinoma of the skin) and } \\
\text { confirmed VTE } \\
\text { Age } \geq 18 \text { years } \\
\text { Weight } \geq 40 \mathrm{~kg} \\
\text { ECOG } \leq 2 \\
\text { Adequate hematologic, he- } \\
\text { patic, and renal function }\end{array}$ & $\begin{array}{l}\text { Active cancer (other than } \\
\text { basal-cell or squamous- } \\
\text { cell carcinoma of the skin, } \\
\text { primary brain tumor or } \\
\text { known intracerebral me- } \\
\text { tastases and acute leuke- } \\
\text { mia) and confirmed VTE }\end{array}$ \\
\hline Exclusion criteria & $\begin{array}{l}\text { Thrombectomy, insertion } \\
\text { of a caval filter, or use of a } \\
\text { fibrinolytic agent to treat } \\
\text { the current episode of } \\
\text { VTE } \\
\text { More than } 72 \text { hours pre- } \\
\text { treatment with anticoag- } \\
\text { ulant treatment prior to } \\
\text { randomization to treat } \\
\text { the current episode } \\
\text { Treatment with therapeu- } \\
\text { tic doses of an anticoagu- } \\
\text { lant other than that used } \\
\text { for pretreatment of the } \\
\text { current VTE episode prior } \\
\text { to randomization } \\
\text { Active bleeding or any } \\
\text { contraindication for } \\
\text { treatment with dalteparin } \\
\text { or edoxaban } \\
\text { Indication for dalteparin } \\
\text { other than VTE } \\
\text { ECOG of } 3 \text { or } 4 \\
\text { Calculated CrCl }<30 \\
\text { mL/min } \\
\text { History of HIT } \\
\text { Acute hepatitis, chronic } \\
\text { active hepatitis, liver cir- } \\
\text { rhosis } \\
\text { Life expectancy }<3 \\
\text { months } \\
\text { Platelet count }<50,000 / \\
\text { mL } \\
\text { Uncontrolled hyperten- } \\
\text { sion } \\
\text { Women of childbearing } \\
\text { potential without proper } \\
\text { contraceptive measures, } \\
\text { and women who are } \\
\text { pregnant or breast feed- } \\
\text { ing } \\
\text { Chronic treatment with } \\
\text { nonaspirin NSAIDs } \\
\text { Treatment with aspirin or } \\
\text { dual antiplatelet therapy } \\
\text { Treatment with the P-gp } \\
\text { inhibitors ritonavir, nelfi- } \\
\text { navir, indinavir, or }\end{array}$ & $\begin{array}{l}\text { Previous treatment dose of } \\
\text { anticoagulant or }>75 \mathrm{mg} \\
\text { aspirin per day } \\
\text { History of VTE, clinically } \\
\text { significant liver disease, bac- } \\
\text { terial endocarditis, active } \\
\text { bleeding or high risk of } \\
\text { bleeding, or uncontrolled } \\
\text { hypertension Inadequate } \\
\text { contraceptive measures if of } \\
\text { childbearing potential } \\
\text { Concomitant use of strong } \\
\text { cytochrome P- } 450 \text { 3A4 } \\
\text { inhibitors or inducers or P-gp } \\
\text { inhibitors or inducers }\end{array}$ & $\begin{array}{l}\text { Age }<18 \text { years } \\
\text { ECOG of } 3 \text { or } 4 \\
\text { Life expectancy of less } \\
\text { than } 6 \text { months } \\
\text { Administration of thera- } \\
\text { peutic doses of LMWH, } \\
\text { fondaparinux, or UFH for } \\
\text { more than } 72 \text { hours be- } \\
\text { fore randomization } \\
3 \text { or more doses of a VKA } \\
\text { before randomization } \\
\text { Thrombectomy, vena } \\
\text { cava filter insertion, or } \\
\text { thrombolysis used to } \\
\text { manage the index epi- } \\
\text { sode } \\
\text { Indication for anticoagu- } \\
\text { lant treatment for a dis- } \\
\text { ease other than the index } \\
\text { VTE episode } \\
\text { Concomitant use of } \\
\text { strong inhibitors or } \\
\text { inducers of both cyto- } \\
\text { chrome P-450 } 3 \text { A4 and P- } \\
\text { gP } \\
\text { Concomitant thienopyri- } \\
\text { dine, aspirin, or dual an- } \\
\text { tiplatelet therapy } \\
\text { Active bleeding or high } \\
\text { risk of bleeding contrain- } \\
\text { dicating anticoagulant } \\
\text { treatment } \\
\text { Recent brain, spinal, or } \\
\text { ophthalmic surgery } \\
\text { Hemoglobin level }<8 \\
\text { g/dL or platelet count } \\
<75,000 / m L \text { or history of } \\
\text { HIT } \\
\text { CrCl }<30 \text { mL/min } \\
\text { Acute hepatitis, chronic } \\
\text { active hepatitis, liver cir- } \\
\text { rhosis } \\
\text { Uncontrolled hyperten- } \\
\text { sion } \\
\text { Bacterial endocarditis } \\
\text { Hypersensitivity to the } \\
\text { study drugs } \\
\text { Women of childbearing }\end{array}$ \\
\hline
\end{tabular}


Table 1 (Continued)

\begin{tabular}{|c|c|c|c|c|c|c|}
\hline \multirow[t]{2}{*}{ Study } & \multicolumn{2}{|c|}{ Hokusai Cancer VTE ${ }^{8}$} & \multicolumn{2}{|l|}{ SELECT-D $^{9}$} & \multicolumn{2}{|c|}{ Caravaggio $^{11}$} \\
\hline & \multicolumn{2}{|c|}{$\begin{array}{l}\text { saquinavir, ketoconazole, } \\
\text { itraconazole, erythromy- } \\
\text { cin, azithromycin, or clar- } \\
\text { ithromycin at the time of } \\
\text { randomization }\end{array}$} & & & \multicolumn{2}{|c|}{$\begin{array}{l}\text { potential without proper } \\
\text { contraceptive measures, } \\
\text { and women who are } \\
\text { pregnant or breast } \\
\text { feeding }\end{array}$} \\
\hline Definition of major bleeding & \multicolumn{2}{|c|}{$\begin{array}{l}\text { Overt bleeding that was } \\
\text { associated with a de- } \\
\text { crease in the hemoglobin } \\
\text { level of } 2 \mathrm{~g} \text { per deciliter or } \\
\text { more, led to a transfusion } \\
\text { of } 2 \text { or more units of } \\
\text { blood, occurred in a criti- } \\
\text { cal site, or contributed to } \\
\text { death }\end{array}$} & \multicolumn{2}{|c|}{$\begin{array}{l}\text { Clinically overt bleeding that } \\
\text { was associated with a de- } \\
\text { crease in the hemoglobin } \\
\text { level of } 2 \mathrm{~g} \text { per deciliter or } \\
\text { more, led to a transfusion of } \\
2 \text { or more units of blood, } \\
\text { occurred in a critical site, or } \\
\text { contributed to death }\end{array}$} & \multicolumn{2}{|c|}{$\begin{array}{l}\text { Clinically overt bleeding } \\
\text { that was associated with } \\
\text { a decrease in the hemo- } \\
\text { globin level of } 2 \mathrm{~g} \text { per } \\
\text { deciliter or more, led to a } \\
\text { transfusion of } 2 \text { or more } \\
\text { units of blood, occurred } \\
\text { in a critical site, necessi- } \\
\text { tated surgical interven- } \\
\text { tion or contributed to } \\
\text { death }\end{array}$} \\
\hline Definition of CRNMB & \multicolumn{2}{|c|}{$\begin{array}{l}\text { Overt not meeting the } \\
\text { criteria for major bleed- } \\
\text { ing, that requires medical } \\
\text { attention or is associated } \\
\text { with discomfort for the } \\
\text { subject such as pain, or } \\
\text { impairment of activities of } \\
\text { daily life }\end{array}$} & \multicolumn{2}{|c|}{$\begin{array}{l}\text { Overt bleeding with medical } \\
\text { intervention } \\
\text { Unscheduled contact with a } \\
\text { physician } \\
\text { Interruption or discontinua- } \\
\text { tion of a study drug } \\
\text { Discomfort or impairment of } \\
\text { activities of daily life }\end{array}$} & \multicolumn{2}{|c|}{$\begin{array}{l}\text { Acute clinically overt } \\
\text { bleeding that does not } \\
\text { meet the criteria for ma- } \\
\text { jor and consists of: } \\
\text { Any bleeding } \\
\text { compromising hemody- } \\
\text { namics } \\
\text { Spontaneous hematoma } \\
\text { larger than } 25 \mathrm{~cm}^{2} \text {, or } \\
100 \mathrm{~cm}^{2} \text { if there was a } \\
\text { traumatic cause } \\
\text { Intramuscular hematoma } \\
\text { documented by ultraso- } \\
\text { nography } \\
\text { Epistaxis or gingival } \\
\text { bleeding requiring tam- } \\
\text { ponade or other medical } \\
\text { intervention or bleeding } \\
\text { from venipuncture for } \\
>5 \text { minutes } \\
\text { Hematuria that was mac- } \\
\text { roscopic and was sponta- } \\
\text { neous or lasted for more } \\
\text { than } 24 \text { hours after inva- } \\
\text { sive procedures } \\
\text { Hemoptysis, hemateme- } \\
\text { sis or spontaneous rectal } \\
\text { bleeding requiring en- } \\
\text { doscopy or other medical } \\
\text { intervention } \\
\text { Any other bleeding con- } \\
\text { sidered to have clinical } \\
\text { consequences for a pa- } \\
\text { tient such as medical in- } \\
\text { tervention, the need for } \\
\text { unscheduled contact } \\
\text { (visit or telephone call) } \\
\text { with a physician, or tem- } \\
\text { porary cessation of a } \\
\text { study drug, or associated } \\
\text { with pain or impairment } \\
\text { of activities of daily life. }\end{array}$} \\
\hline Anticoagulant & Edoxaban & Dalteparin & Rivaroxaban & Dalteparin & Apixaban & Dalteparin \\
\hline Mean age, years & 64.3 & 63.7 & $67^{\mathrm{a}}$ & $67^{\mathrm{a}}$ & 67.2 & 67.2 \\
\hline Weight, kg & 78.8 & 79.1 & - & - & 75.7 & 76.1 \\
\hline
\end{tabular}


Table 1 (Continued)

\begin{tabular}{|l|l|l|l|l|l|l|}
\hline Study & \multicolumn{2}{|l|}{ Hokusai Cancer VTE } & \multicolumn{2}{l|}{ Caravaggio $^{11}$} \\
\hline $\mathrm{CrCl}<50 \mathrm{~mL} / \mathrm{min}, \%$ & 7.3 & 6.5 & - & - & 8.9 & 10.5 \\
\hline Metastatic disease, \% & 52.2 & 53.4 & 58 & 58 & 67.5 & 68.4 \\
\hline Anticancer treatment, \% & 71.6 & 73.1 & 69 & 70 & 60.8 & 63.4 \\
\hline Major bleeding, \% & 6.9 & 4.0 & 5.4 & 3.0 & 3.8 & 4.0 \\
\hline CRNMB, \% & 14.6 & 11.1 & 12.3 & 3.4 & 9.0 & 6.0 \\
\hline Major or CRNMB, \% & 18.6 & 13.9 & - & - & 12.2 & 9.7 \\
\hline Major Gl bleeding, \% & 3.8 & 1.1 & 3.9 & 2.0 & 1.9 & 1.7 \\
\hline
\end{tabular}

Abbreviations: $\mathrm{CrCl}$, creatinine clearance; CRNMB, clinically relevant nonmajor bleeding; ECOG, Eastern Cooperative Oncology Group; GI, gastrointestinal; HIT, heparin-induced thrombocytopenia; LMWH, low-molecular-weight heparin; NSAID, nonsteroidal anti-inflammatory drug; P-gp, P-glycoprotein; UFH, unfractionated heparin; VKA, vitamin K antagonist; VTE, venous thromboembolism.

${ }^{\mathrm{a}}$ Median values.

(HR, 1.38; 95\% CI, 0.98-1.94). In a subgroup analysis of patients with gastrointestinal cancer, major bleeding rates favored dalteparin therapy (edoxaban $13.2 \%$ vs. dalteparin $2.4 \% ; p=0.02$ ). Bleeding rates were similar in the patients with nongastrointestinal cancer. There were no fatal bleeding events in the edoxaban arm and one fatal bleed in the dalteparin arm. In the SELECT-D trial, major bleeding rates were $6 \%$ for rivaroxaban and $4 \%$ for dalteparin (HR, $1.83 ; 95 \% \mathrm{Cl}, 0.68-4.96) .{ }^{9}$ Most major bleeding events involved the gastrointestinal tract. Patients with upper gastrointestinal cancer were more likely to experience a major bleed with rivaroxaban compared with dalteparin. CRNMB was also more frequent with rivaroxaban (13\% vs. $4 \%$; $\mathrm{HR}, 3.76$; 95\% CI, 1.63-8.69) and primarily involved gastrointestinal or genitourinary sources.

The potential explanations for the differences in the risks of major bleeding events remain debatable, including the differences in patient characteristics, protocol designs, distinct prespecified bleeding definitions, the anticoagulant dose or frequency (once vs. twice daily dosing), or other factors (-Table 1). The baseline characteristics of the patients randomized in Caravaggio were comparable with those of the previous studies. ${ }^{8,9}$ There were similar percentages of enrolled patients with gastrointestinal cancers as well as with active and metastatic cancers in these trials. The proportion of patients who were receiving anticancer treatment or had moderate renal insufficiency were also comparable. However, the presence of active luminal tumors (i.e., luminal gastrointestinal or genitourinary tumors) was not reported in either study. In addition, there were minor differences in the definition of major bleeding across these four trials (-Table 1). Nevertheless, similar rates of major bleeding event rates in the dalteparin arm of these trials
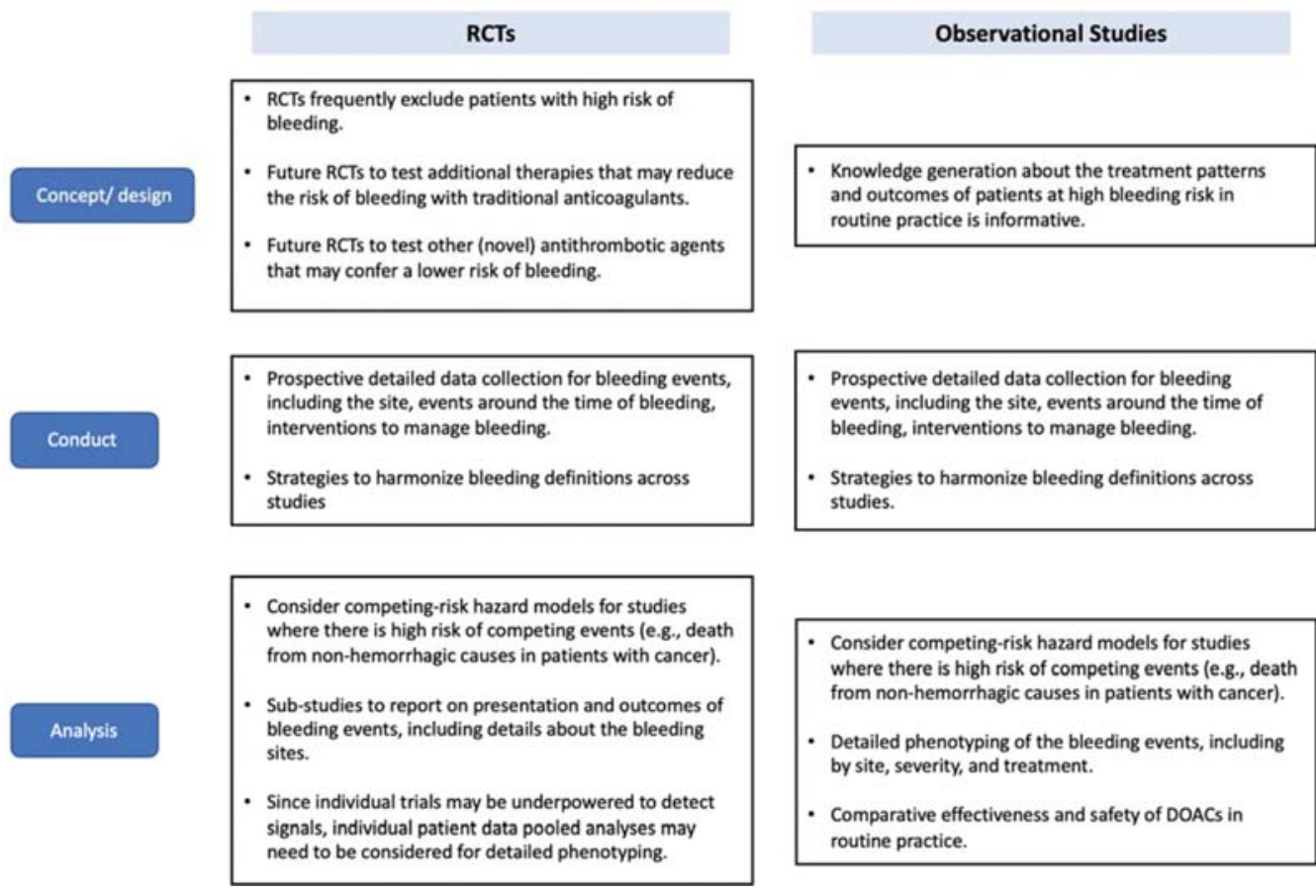

- Strategies to harmonize bleeding definitions across studies.

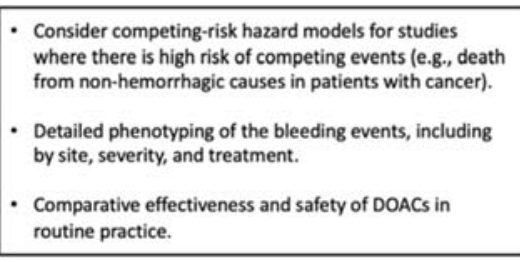

Fig. 1 Considerations for improved knowledge generation for bleeding events in patients receiving anticoagulant therapy. DOACs, direct oral anticoagulants; RCTs, randomized controlled trials. 
make it unlikely that a large difference in case mix existed between them. Importantly, dabigatran, has not been specifically studied in this subgroup of patients.

What do we learn from this study for our clinical practice? DOACs provide an attractive alternative to LMWH in the treatment of VTE in cancer patients. ${ }^{15}$ At present, due to conflicting data, the use of DOAC for patients with gastrointestinal or urological malignancies would appear risky. If they have to be used for these patients, indirect comparisons suggest that apixaban might be the safest of the DOAC medications. Since it is unlikely that different DOACs will be compared in randomized controlled trials in near future, evidence derived from routine practice can provide key insights regarding how each anticoagulant is used under routine care conditions in diverse patient populations (-Fig. 1). For that purpose, data from large registries will complement the perspective from randomized studies. ${ }^{16-18}$

\section{Conflict of Interest}

B.B. reports that he is a consulting expert, on behalf of the plaintiff, for litigation related to a specific type of IVC filters. D.J. has served as an advisor or consultant for Bayer HealthCare Pharmaceuticals, Boehringer Ingelheim, Bristol-Myers Squibb, Daiichi Sankyo, Leo Pharma, Pfizer, ROVI, and Sanofi; served as a speaker or a member of a speakers' bureau for Bayer HealthCare Pharmaceuticals, Boehringer Ingelheim, Bristol-Myers Squibb, Daiichi Sankyo, Leo Pharma, ROVI, and Sanofi; received grants for clinical research from Daiichi Sankyo, Sanofi, and ROVI.

\section{References}

1 Giustozzi M, Curcio A, Weijs B, et al. Variation in the association between antineoplastic therapies and venous thromboembolism in patients with active cancer. Thromb Haemost 2020;120(05):847-856

2 Prandoni P, Lensing AW, Piccioli A, et al. Recurrent venous thromboembolism and bleeding complications during anticoagulant treatment in patients with cancer and venous thrombosis. Blood 2002;100(10):3484-3488

3 Kearon C, Akl EA, Ornelas J, et al. Antithrombotic therapy for VTE disease: Chest guideline and expert panel report. Chest 2016;149 (02):315-352

4 Konstantinides SV, Torbicki A, Agnelli G, et al; Task Force for the Diagnosis and Management of Acute Pulmonary Embolism of the European Society of Cardiology (ESC) 2014 ESC guidelines on the diagnosis and management of acute pulmonary embolism. Eur Heart J 2014;35(43):3033-3069
5 Montroy J, Lalu MM, Auer RC, et al. The efficacy and safety of low molecular weight heparin administration to improve survival of cancer patients: a systematic review and meta-analysis. Thromb Haemost 2020;120(05):832-846

6 Akl EA, Kahale L, Barba M, et al. Anticoagulation for the long-term treatment of venous thromboembolism in patients with cancer. Cochrane Database Syst Rev 2014;7(07):CD006650

7 van Es N, Coppens M, Schulman S, Middeldorp S, Büller HR. Direct oral anticoagulants compared with vitamin $\mathrm{K}$ antagonists for acute venous thromboembolism: evidence from phase 3 trials. Blood 2014;124(12):1968-1975

8 Raskob GE, van Es N, Verhamme P, et al; Hokusai VTE Cancer Investigators. Edoxaban for the treatment of cancer-associated venous thromboembolism. N Engl J Med 2018;378(07):615-624

9 Young AM, Marshall A, Thirlwall J, et al. Comparison of an oral factor Xa inhibitor with low molecular weight heparin in patients with cancer with venous thromboembolism: Results of a randomized trial (SELECT-D). J Clin Oncol 2018;36(20):2017-2023

10 McBane RD II, Wysokinski WE, Le-Rademacher JG, et al. Apixaban and dalteparin in active malignancy-associated venous thromboembolism: the ADAM VTE trial. J Thromb Haemost 2020;18(02): 411-421

11 Agnelli G, Becattini C, Meyer G, et al; Caravaggio Investigators. Apixaban for the treatment of venous thromboembolism associated with cancer. N Engl J Med 2020;382(17):1599-1607

12 Haykal T, Zayed Y, Deliwala S, et al. Direct oral anticoagulant versus low-molecular-weight heparin for treatment of venous thromboembolism in cancer patients: an updated meta-analysis of randomized controlled trials. Thromb Res 2020; 194:57-65

13 Giustozzi M, Agnelli G, Del Toro-Cervera J, et al. Direct oral anticoagulants for the treatment of acute venous thromboembolism associated with cancer: a systematic review and metaanalysis. Thromb Haemost 2020;120(07):1128-1136

14 Ageno W, Vedovati MC, Cohen A, et al. Bleeding with apixaban and dalteparin in patients with cancer-associated venous thromboembolism: results from the Caravaggio study. Thromb Haemost 2021;121(05):616-624

15 Picker N, Lee AY, Cohen AT, et al. Anticoagulant treatment in cancer-associated venous thromboembolism: assessment of patient preferences using a discrete choice experiment (COSIMO study). Thromb Haemost 2021;121(02):206-215

16 Weitz JI, Haas S, Ageno W, et al. Global anticoagulant registry in the field - venous thromboembolism (GARFIELD-VTE). Rationale and design. Thromb Haemost 2016;116(06):1172-1179

17 Bikdeli B, Jimenez D, Hawkins $M$, et al; RIETE Investigators. Rationale, design and methodology of the computerized registry of patients with venous thromboembolism (RIETE). Thromb Haemost 2018;118(01):214-224

18 Cohen A, Keshishian A, Lee T, et al. Effectiveness and safety of apixaban, low-molecular-weight heparin, and warfarin among venous thromboembolism patients with active cancer: a U.S. claims data analysis. Thromb Haemost 2021;121(03):383-395 